\title{
The Blikstad Family: Saga of Emigrants in Norway, Spain, and Brazil
}

\author{
María Álvarez-Solar
}

\section{Introduction}

My purpose is to write about a Norwegian family named Blikstad, characterized by several generations of emigrants throughout a period of over two hundred years. The last one of these generations, to which I will refer in this research, settled around 1940 in Brazil, where many of its descendants still live. I will also refer to other generations that had previously emigrated both within Norway itself and especially to Spain.

I was interested in studying the migratory route of this family for several reasons, including the strong ties that I observed, the migratory decisions of its members, the migratory chains created to help the members develop their careers in the countries of settlement, and the strategies that they developed in the different economic settings with their diverse employment or capital investment possibilities. It was also of great interest to me to know how the family members created not static but fluid migratory spaces through the borders: their interaction with the societies they settled in Spain and Brazil are linked to the Norwegian society of origin. These ties are economic in nature, both in the transnational economic space, as created by the internationalization of the financial and commerce systems, and in the social space, with the designing of networks. The various migrations of the Blikstads started at the end of the eighteenth century and the beginning of the nineteenth century, when members of the family emigrated from the countryside in Eastern Norway to the city of Christiania (now Oslo), and in the process they changed from farmers to craftsmen. Some members of the following generation moved to Copenhagen to study more specialized trades, and then they settled in other Norwegian cities, like Trondhjem (now Trondheim) in the west or Christianssand (now Kristiansand) in the south, to practice their profession. Around 1880 a third generation of the Blikstads emigrated to Spain, where they established timber companies and later entered the shipping industry, purchasing some ships for that purpose. By 1905, they had invested part of the capital obtained from those activities in the Norwegian textile sector, and 
became major shareholders of Nydalen, the biggest Norwegian textile company at that time. At the beginning of the 1940s, the fifth generation of the Blikstads emigrated, to Brazil in this case, not as entrepreneurs but as specialized workers employed by international companies. So, the migratory routes of the family over this extensive period were characterized by occupational and business diversification and by the frequent relationships with international companies and global commerce. In this sense, it can be said that the Blikstads moved in the world of transnationalism, in the economic sense of the term, a trend much discussed in the academic sphere in recent years and addressed further below. Among those descendants of the Blikstads I got in touch with, and to whom I will later return, this repeated migratory activity through different generations has produced a narrative about the family identity that can be viewed as a saga, in the sense of an epic of travelers, of migrants who, through the centuries, moved and move nimbly in the international spaces thanks to their migratory experience, their networks, and the economic and social capital that they gradually accumulated.

Different generations of the Blikstads moved, and still move, in those spaces without ever losing contact with Norway and the part of the family living there. In their comings and goings, they designed networks of strong ties that helped them in their migrations by forming real chains of support and exchange of experiences and work opportunities. In this, they differ from those Norwegians who emigrated to Latin America with limited contacts in the countries they settled in, and with only weak-tie networks, which sometimes gives an air of adventure to their migrations, an air that such Norwegians were aware of themselves and recorded in their traveler books and personal diaries. The Blikstads, on the contrary, are not frustrated adventurers but rather have several generations' worth of experience of migratory processes. Both this expertise and their networks - not only of strong family ties, as mentioned above, but also of weak ties with people they contact in their entrepreneurial itineraries - led them to undertake planned and seasoned migrations. In this respect, the individual Blikstads I will cite in this paper did not write diaries or traveler books. Though they seemed to control their migratory movements themselves, the study of their itineraries will show that this seeming control was apparent only; like other workers and entrepreneurs in the international spaces, they were affected in their migratory decisions by changes in the global economy, which were very significant between 1880 and 1940, and which impacted on their enterprises and their chances to get work, sometimes positively and sometimes adversely.

The Blikstads are, in this sense, transnational migrants, what has come to be known since the last century as transmigrants. In the academic sphere the 
approach to migrations as transnational phenomena was defined with authority by Nina Glick Schiller, Linda Basch, and Cristina Szanton-Blanc, who defined transmigrants as those who

construct social fields that connect their country of origin to their country of settlement. Transmigrants develop and maintain multiple relationships family, economic, social, organizational, religious, political - that transcend borders. Transmigrants act, make decisions, and feel involved, and they develop identities within the social networks that connect them simultaneously to two or more societies. ${ }^{1}$

The main goal of this research on the Blikstads was originally to study those family members who had emigrated to Brazil. Later, however, when coming into contact with their stories, I realized that the picture of their migratory experience could not be understood without seeing them in the context of the migratory experiences of previous generations of the family. I therefore mapped out their relational networks and created transnational spaces transcending the concepts of countries of emission and reception as well as the state perspectives of their migratory movements. The theoretical approach to transnationalism applied to the study of migrations was of great help to acquire this image.

In this sense, the Blikstads are not a unique case; other Norwegian families settled in both Spain and Brazil around the same time, and we can see that there were important parallels in their career paths. The period favorable to the development of businesses in the Europe of 1870-1900, characterized by the economic growth in spite of the cyclical crisis, led to a boost in business and entrepreneurial activities that attracted families like the Blikstads and the Sörensens. These families were entrepreneurs with their own capital who founded companies favored by the demand of raw materials such as wood. They are not emigrants who settle in a country and lose contact with the countries they come from; on the contrary, they generate economic, social, and cultural links in both countries, and exemplify what in the study of migrations has come to be known as transnationalism.

1 Nina Glick Schiller et al., "Towards a Definition of Transnationalism. Introductory Remarks and Research Questions" in Towards a Transnational Perspective on Migration: Race, Class, Ethnicity and Nationalism Reconsidered, ed. Nina Glick Schiller, L. Basch and C. SzantonBlanc (New York: New York Academy of Sciences, 1992);Spanish version in Carlota Solé , Sonia Perellá and Leonardo Cavalcanti (eds.) Nuevos retos del transnacionalismo en el estudio de las migraciones (Madrid: Ministerio de Trabajo e inmigración, 2008). 
Since the end of the 1980s, Glick, Basch, and Szanton-Blanc have made it clear that it is not possible to study the emigrants just on the territory of a nation-state of settlement,

because their lives take place at both sides of the borders. And when Linda Basch, Cristina Szanton-Blanc, and I said that they live at both sides of the border, we didn't mean that they were in constant move from one country to another, but that their lives take place within social environments - networks of networks - that connect them to the social, economic, political, and religious institutions from two or more statenations. To this, we analyzed the formation processes of the state-nation, as well as the family and commercial ties, and the cultural and religious organizations and activities that transcended the national borders. ${ }^{2}$

In the academic discussion on transnationalism the concept of transnationalism has been often associated with that of globalization, in the sense that faster and lower-cost transportation would make easier the transnationalization of migrants, whom we denominate transmigrants, as I have already mentioned. Nevertheless, Glick herself made it perfectly clear that transnationalization is not a phenomenon associated with globalization but a study approach to migrations in the era of globalization.

I was also interested in knowing more about the networks established by the Blikstads in Brazil and what their ties in Norway were like. As mentioned above, I think it is necessary to consider the migratory behaviors of the ancestors of these immigrants to Brazil. This will lead me to study the migration, around 1880 , of the patriarch of the Blikstad family to Asturias in Spain. In short, the choice of the Blikstad family as the object of this research is aligned with the view of transnationalism as a theoretical tool for studying the migratory movements of the family. In this sense, determining the design of the family networks and contacts on both sides of the Atlantic will be an objective in this chapter.

There are three members of the Blikstad family mentioned in this work who share the same first name and surname: Magnus Torbjørnsen Hauff Blikstad (1862-1926), his son Magnus Torbjørnsen Blikstad (1897-1979) the latter's son Magnus Torbjørnsen Blikstad (1921-2002); in order to ease the reading I will refer to them as Blikstad I, II, and III respectively. I consider the grandfather, a great entrepreneur, as the patriarch of the Blikstads, as he laid the foundations of the family capital and economic ascent, and also because in his migratory

2 Ibid. 
traveling he created a transnational space that enriched his family both culturally and financially, as well as the countries where he settled in, as we will shortly see. The other Blikstad I will highlight is Blikstad III, the grandson of the patriarch; with an itinerary covering Spain, Norway, and Brazil, he is the center of our study and the focus of the following section. As this anthology is about Norwegians who emigrated to Latin America, I will start with those Blikstads who moved to Brazil.

\section{The Migration to Brazil of Magnus Torbjørnsen Blikstad and other Relatives}

In the 1940s Magnus Torbjørnsen Blikstad (Santander, Spain, 1921-São Paulo, 2002; henceforth Blikstad III) traveled from Norway to Spain in search of work, relying on the contacts established by his father and especially his grandfather through their previous business activity in that country. The economic isolation of Spain after the Civil War (1936-39) prevented the young Magnus from accomplishing his plan. He then traveled to Brazil, where he arrived in 1948 for a job offer from the American company Anderson Clayton. ${ }^{3}$ He would work there for that company all through his working life, first in the coffee division in Santos and then from 1960 on in the margarine division in São Paulo. In the 1950s, his brother Bernhard and his cousin Alf Blikstad also emigrated to Brazil; however, this family migration to Brazil was definitive only in the case of Blikstad III, since both his brother and his cousin returned to Europe years later. ${ }^{4}$

Magnus T. Blikstad III was married in 1950 in Brazil to the Brazil-born Kirsten Emilie Sigmond, the daughter of Harald Sigmond and Ablaug Sigmond (née Barfod), ${ }^{5}$ who were Norwegian immigrants to Brazil (curiously enough, they happened to meet in Norway on a coincidental trip there). Harald Sigmond had been born in Zumbrota, Minnesota, in 1884, the son of Norwegian immigrants to the United States. Years later his family returned to Norway,

3 All the biographical details about Magnus Torbjørnsen Blikstad were given to me in the autumn of 2012 by his eldest daughter Vivien Blikstad, who lives in Brazil, over a series of very valuable interviews through Skype and e-mail that allowed me to know about the lives of her parents and of herself in Brazil.

4 My main source of information, Vivien Blikstad, did not remember exactly how many years they lived in Brazil.

5 The surname Barfod comes from Langesund in Telemark, Norway. Interview with Vivien Blikstad, October, 2012. 
from where Harald emigrated to Brazil ${ }^{6}$ in the 1930 in response to a job offer as an engineer for the construction of the Swedish-financed Fiat Lux match factory. Magnus and Kirsten maintained links with Norway all through their lives, sending their four children to study there, but remaining themselves permanently in Brazil. Of their children, only one daughter came back and still lives in Norway. As for the rest of the Blikstad immigrants to Brazil, there is a son of Bernhard Blikstad still living in that country. A photograph which Vivien sent me shows Magnus and Kirsten, just married, on a beach day in Brazil. For their daughter Vivien Blikstad this photo represents the happiness her parents felt in Brazil.

Instrumental in the success of this immigration were the possibility of work and the immigration policy of Brazil at that time. People with a higher education were much in demand, as was the case with Harald Sigmond. In the 1930s, during the administration of Getulio Vargas, the intellectuals, with the approval of the government, had formulated a policy on immigration strengthening the Brazilian elements based on the Portuguese language and on the local culture. This idea would crystallize in the Constitution of 1946, where article 162 determined that "the selection, entry, distribution, and settlement of immigrants were subjected under the law to the demands of the national interest." The goal pursued at that time was the arrival of immigrants who could serve the progress of the country. ${ }^{7}$

The Brazilian economic policy at the time also encouraged the establishment of foreign companies in the country. This was the case of the Anderson Clayton Company, which had started its commercial activity in the cotton sector in 1910, expanding into the coffee and margarine sectors years later. The company had been operating in Mexico since 1921, and later incorporated other Latin American countries, like Brazil, Argentina, Peru, and Paraguay. ${ }^{8}$ Anderson Clayton had agents in several European countries, one of them Spain, where the company frequently appeared in advertisements of the time. ${ }^{9}$ Forty years later, the American company had diversified its production, and like other foreign companies, mostly British and American, it invested in Latin

6 Harald Sven Sigmond arrived in Brazil in 1935, heading from Rio de Janeiro to Santos. Archivo Público del Estado de Sao Paulo, Centro Histórico do Inmigrante, SisT-MCF. Lista General de Desembarque de Passsageiros. Microfilm oo3/LDP HULA. 1949o-.

7 Elda Evangelina González Martínez, La inmigración deseada: La política migratoria brasileña desde João vi hasta Getúlio Vargas (Madrid: Consejo Superior de Investigaciones Científicas, 2003).

8 William Argue, "History of Anderson, Clayton and Company," Journal of the American Oil Chemists Society 37:6 (1960), 4-8.

9 For instance in Industria textil (Barcelona). 
America and needed workers with technical, administrative, and commercial training.

Magnus T. Blikstad II s spoke fluent Norwegian, English, and Spanish and had studied at Oslo Handelsgymnasium in Norway, which made him a good candidate for Anderson Clayton. ${ }^{10}$ In the nineteenth century many countries in Europe, including Norway, had a surplus of highly qualified workers. In this respect, Stang concluded that the Norwegian labor market could not absorb technicians and other professionals with a higher education during that period. ${ }^{11}$ Mörner points out that the same occurred in Belgium, and possibly in other European countries:

While the vast majority of European immigrants to Latin America...were poor and uneducated, this has always coexisted with another element, small in number but qualitatively significant, of advanced-trained technicians and professionals. ${ }^{12}$

As for Norway, the situation had not improved in the 1940 .

In a few words, the Blikstads and the Sigmonds were well accepted in Brazil both by the international companies and the government, and can be therefore considered as desired immigrants. Besides, Magnus Blikstad II I was nothing of an adventurer immigrant guided by chance, since he had networks of contacts and a long family tradition of migration.

\section{Routes and Ascent of the Blikstads}

The Blikstads' migratory tradition dated from almost two hundred years before the arrival of Blikstad III to Brazil and his working for the Anderson Clayton company. The Blikstads had begun by emigrating from the countryside to the city at the end of the eighteenth century and the first years of the nineteenth century. They moved from the southeast of Norway, where they were farmers,

\footnotetext{
10 The commercial and business education in Norway was imparted at that time in high school institutes specialized in those subjects, which were called handelgymnasium. The Oslo Handelsgymnasium started its activity in 1877 .

11 Gudmund Stang, "La emigración escandinava a la América latina, 1800 - 1940," Jahrbuch für Geschichte Lateinamerikas 13 (1976), 293-330.

12 Magnus Mörner, Historia social latinoamericana (Nuevos enfoques) (Caracas: Universidad Católica Andrés Bello, 1979), 102.
} 
to the city of Christiania to work as artisans. Ole Peter Blechstad, ${ }^{13}$ born in $1794,{ }^{14}$ learned the craft of blacksmith ${ }^{15}$ in Christiania, where in 1820 he married Anne Magdalene Lutken/Lütken (b. 1799). ${ }^{16}$ One of their children, Hakon Napoleon Blikstad (1827-90), ${ }^{17}$ moved to Copenhagen to learn the craft of his father. Once he mastered it, he specialized in cutlery and surgical instruments, producing high quality pieces. ${ }^{18}$ Some years later, Hakon Napoleon moved to Trondhjem, maybe to get a bigger and better clientele, and he seems to have succeeded, since the census of 1865 shows him with a house of his own on 15 Tordenskjold Gate, where he lived with his wife Engelbærtine Bente Antonæte Hauff (1827-1891), from Christianssund (now Kristiansund), and their five children. From the same census, we know he had three apprentices and two female servants. ${ }^{19}$ He must have been a man with a liberal frame of mind, interacting with people from different places. ${ }^{20}$ Around 1880, one of his children, Magnus - that is, Magnus Torbjørnsen Hauff Blikstad (1862-1926), the future Blikstad family patriarch ${ }^{21}$ - traveled to Spain. In those years the wood import business was blooming in Spain, and several Norwegians had gone into what looked like a promising activity.

As stated, Blikstad I's father, Hakon Napoleon, was an open-minded man who very likely came into contact with people from different countries who arrived in the city of Trondhjem to go fishing (besides his specialties in cutlery and surgical instruments, Hakon Napoleon Blikstad was also a specialist in

13 Blechstad would be the Danish for Blikstad.

14 The son of Knud Blechstad, a blacksmith from Allunværket (an area or neighborhood of Christiania). Ole Peter was born in Allunværket in 1794. Ministerialbok Oslo hospital. Gamlebyen prestegjeld 1734-1818 (o39 t M13) http://digitalarkivet.no.

15 Kolstad, Knivbladet 5 (1991).

16 According to Per Thoresen, in Knivprat, Ana Magdalena Lutken was the daughter of the manager of Hurdal Glassverk, a glass manufacturer. http://kniver.blogspot.no/.

17 "Norway, Baptisms, 1634-1927," index, FamilySearch https:/familysearch.org/pal:/ MM9.1.1/NHSR-8R7: accessed 24 Sep 2012), Hakon Napoleon Petersen, 06 May 1827; citing reference 2:1SDQ7N9, FHL microfilm 125786.

18 Koldstad's work offers a very detailed summary of the cutlery work of Hakon Napoleon Blikstad. See Harald Kolstads introduction in Knivbladet 6 (1992).

19 Digitalarkivet. Census of 1856 . Trondheim.

20 See Thoresens blog http://kniver.blogspot.no/search/label/Blikstad.

21 Magnus Torbjørnsen Hauff Blikstad (1862-1926), the grandfather in this saga, married Ane Olava/Anita Blikstad (née Kulø, 1861-1950) with whom he had the following children: Eduardo (b. Gijón, 1888), Angelita (b. Gijón, 1891), Marie/Minni/Mimi (b. Gijón, 1894), Haakon (b. Gijón, 1895), Magnus (b. Gijón, 1897), Augusta/Anita (b. Bærum, Akerhus, 1900), and Alf (b. 1902). 
hooks and fishing implements). It was probably through those casual networks of weak ties that the young Magnus T. Blikstad I would be inspired to settle in Spain in a business that promised to be very lucrative and interesting. Besides, his father-in-law was also engaged in the fishing sector and the fishing ship industry. The contacts between the north of Spain, where Asturias is located, and the west coast of Norway, where the Blikstads lived, had been traditionally numerous already since the Middle Ages, because of the fishing and trade of cod, which at the time was a highly appreciated product in Spain, where he was appointed consul of Sweden and Norway and started a timber and mechanics company in Gijón in Asturias. He later became the director and main owner of the Madrid-based timber company Compañía de Maderas, which various branches throughout Spain, including Gijón. ${ }^{22}$

Between 1870 and 1890 , Norway was a big exporter of timber. It is a country rich in conifer trees, which grow profusely in the boreal areas and whose wood was highly sought after at a time when the Industrial Revolution demanded the exploitation of coal mines and the construction of railways. ${ }^{23}$ Between $185^{\circ}$ and 1900 the mining area in the north of Spain required a railway to carry the mineral to the exportation ports in the Cantabrian Sea: Bilbao, Santander, and Gijón. The economic situation was favorable to the timber industry at that time, both in Norway and Spain, encouraged by the Commerce Treaty signed by King Oscar II of Sweden and Norway and King Alfonso XII of Spain in 1883 to promote the commercial exchange and the relationships among these countries. ${ }^{24}$ Apart from Consul Blikstad, other Norwegian entrepreneurs had established themselves in Spain in those years to enter the timber business, such as Birger Sörensen, from Fredrikstad, who established himself in Madrid in 1878 to run his father's timber company, the Compañia de Maderas Sörensen. This company was one of five plants operating in Bilbao in the last third of the nineteenth century, some of them being imported wood warehouses. ${ }^{25}$ The company's full name was Sörensen Yakhelnn \& Compañía. Other Nordic timber companies included the one owned by Hilario Lund y Clausen (in Ripa), who was a cod trader and consul of Sweden and Norway in Bilbao. ${ }^{26}$ As seen from

\footnotetext{
22 Nordmanns-Forbundet, 130.

23 For a detailed article on this point that treats the timber trade, see Iñaki Iriarte Goñi, "La inserción internacional del sector forestal español 1849-1935," Revista de Historia Industrial Xvi:27 (2005), 13-46.

24 Boletín Oficial de la Provincia de Tarragona, 159.

25 N. de la Puerta Rueda, La Compañía de maderas. (Bilbao: Diputación Foral de Bizcaia, 1994), 25 .

26 Susana Serrano Abad, "Paisaje e industria en el Bilbao del despegue (1860-1930)," Historia contemporánea 24 (2002), 223-42.
} 
the above, the entrepreneurial activity of those Norwegians went together with their diplomatic activity as consuls. As Norway was in a personal union with Sweden at that time, these men served as consuls of both Sweden and Norway, and were sometimes taken for Swedish in the documentation, as in the case of Sörensen, who sometimes appears as Swedish and sometimes as Norwegian. So, it is clear that, as a minority (of Nordic immigrants), there were surely contacts among these entrepreneurs on account of consular, entrepreneurial, and commercial issues.

The capital accumulated by Consul Blikstad through his business activities in Spain would allow him to make new business investments during the period prior to World War I. He then returned to Norway in 1905, and invested in the textile industry, purchasing the majority of shares of Nydalen, a textile manufacturer founded in 1845 and the one that employed the most workers in Norway at that time. His three male children would join the company's board of directors at different moments in time: Eduardo (the eldest), Haakon, and Magnus (i.e., Blikstad II).

Blikstad I invested in the shipping sector, founding two companies in 1915: DS Gijonés and DS Maderas, with two steamboats named after each one of them. Subsequently he founded the company DS Vale in 1916, with the steamboat Vale. ${ }^{27}$ In 1919 all the three ships were finally brought together into a company called Skibs-AS Maderas based in Hølen, Akershus (Norway). ${ }^{28}$ The Vale, which he had bought in 1916, was sunk by the Germans on the Newcastle-Bergen route during World War I, in 1917; three men died in the wreck. ${ }^{29}$ Another of the company's ships, the Carlos, stranded in Kullebunden, Jeløya, on the Kristiania-Moss route in $1919 .{ }^{30}$ When the war was over, the shipping company continued to operate until 1926, two years after the death of the family patriarch.

Blikstad I considerably increased his family's capital. Returning to Norway, he lived in Bærum, one of the most affluent suburban districts of Kristiania, enjoying a comfortable but not lavish lifestyle. A family photo from those years shows the Blikstads with a respectable but unpretentious appearance. ${ }^{31}$ The photo focuses on the family bond rather than on luxury; Mrs Blikstad is wearing not a single jewel, which could make us suspect a pietist family, but there is no data on this in the family memory. In my view, considering the social and

\footnotetext{
27 Interview with Vivien Blikstad. Skype. October, 2012.

28 Ibid.

29 Norwegian wrecks in 1917, and in 1919. Norsk Skipsfartshistorisk Selskap.

$30 \quad$ Norsk Skipsfartshistorisk Selskap. The ship ran aground because of risky navigation in the mist.

31 See photograph of Magnus T. Hauff Blikstad (Blikstad I) with wife and children by Phos Foto at Oslo byarkiv (http://www.oslobilder.no/BAR/A-10093/Ua/ooo1/154).
} 
cultural work carried through by Blikstad I in Gijón as well as his local press statements, he was an entrepreneur with a humanist mindset and a liberal attitude, most assuredly inherited from his father Hakon Napoleon and his grandfather Ole Peter. It is very likely that he was a Mason, since many of the Gijón bourgeoisie who helped found the Ateneo Obrero (Workers' Athenaeum) were liberal Masons. The interest in the cultural promotion of workers is also shown by other immigrants in Gijón, with whom Blikstad I had contact, like Ernesto Winter Blanco, the son of an Alsatian immigrant who had come to Gijón to work at the Cifuentes, Pola y Cía glass factory. Ernesto was an engineer and much concerned with the subject of education. He also had contacts with entrepreneurial families in Asturias, like the Figaredo, Bustelo, and Orueta. ${ }^{32}$

To the economic capital contributed by Blikstad I must be added the social capital accumulated through ties created in Spain (and perhaps previously in Trondhjem with the help of his father, Hakon Napoleon). ${ }^{33}$ These ties, both at a local and national level in Spain, can be considered as weak, yet important in order to get relevant information in the work field so as to get an employment, or in business. ${ }^{34}$ One example of this social activity was his civic involvement by collecting signatures from Gijón entrepreneurs and businessmen, calling for the government to construct a new and deeper harbor in Gijón (El Musel) where large ships could dock. ${ }^{35}$ His civic engagement with social and cultural projects like the creation in Gijón of the Workers' Athenaeum, of which he was a great benefactor, led him to establish bonds with the liberal bourgeoisie and the intellectual Left that supported and had founded the Athenaeum. During the years he lived in Asturias, other international companies had established themselves in the region, like La Compagnie Royale Asturienne des Mines, which focused on the mining of zinc, iron, and coal, and of which the Norwegian company De Norske Zinkverker, located in Odda, Hordaland (Norway), ${ }^{36}$ was a branch. In his capacity as consul of Sweden and Norway, Blikstad I would have relationships with this company, and the business relationships with Spain continued after his death. For instance, his eldest son,

32 María Fernanda Fernández Gutierrez, "Estudio histórico artístico del orfanato minero," Boletín de letras del Real Instituto de Estudios Asturianos , 157(Enero-Junio 2001), 127-245.

33 Pierre Bourdieu, "Le capital social. Notes provisoires," Actes de la recherche en sciences sociales $3^{1}$ (Janvier 1980); James Coleman, "Social Capital in the Creation of Human Capital," American Journal of Sociology 94 (1988), 95-120.

34 Mark S. Granovetter, "The strength of weak ties," American Journal of Sociology 78:6 (1973), 1360-80.

35 Signatures for the new port of El Musel (Gijón).

36 Nordmanns-Forbundet: 131 . 
Eduardo Blikstad, hosted the Navy officers in his house on occasion of the visit to Oslo of several Spanish warships in $1929 .{ }^{37}$

In addition to both their economic and social capital, the Blikstads had a cultural capital provided by the education they had received. The interest in education also expressed itself in the philanthropic work of Blikstad I in Spain. Much of his work there was that of supporting workers' education, with the creation of libraries and cultural magazines. The consul gave his children a commercial education like the one he had himself (we know very little about his daughters). All of them studied in Norway at the Norwegian School of Economics, and spent study periods in other European countries like England and France.

In summary, the economic ascent was strongly determined by both the economic contexts and the Blikstads' weak ties with other companies or economic or social groups. This benefited the family companies and strengthened the already strong family ties, since all of the consul's sons worked in those companies at some point. On his return to Norway, nevertheless, it is more doubtful that the social ascent paralleled the economic one. The Blikstads did not belong to the elite of civil servants from the Norwegian high bourgeoisie. Blikstad I participated in the political life of the country for a short time, and was the mayor of Bærum from 1917 to 1919. During his term in office, he founded a scholarship for young students. ${ }^{38}$ If the global economic context had shaped the possibilities of success for Blikstad I in his migration to Spain and in his investments in Spain and Norway, the financial crisis of 1930 would mean a hard hit that, in the case of Spain, worsened with the Civil War in 1936-39, and, in the case of Norway, with World War II. Soon before, the Blikstads started to face the British competition in the shipping of goods, and British protectionism meant more obstacles for their companies. The prospects at that time were not very promising for Blikstad I's grandsons, Magnus (Blikstad III), Bernhard, and Alf, who decided to emigrate to Brazil.

\section{Identity and Family Memory of the Blikstads}

Were they Norwegian, Brazilian, or world citizens? The first members of this family I got in touch with were Sara and Marta, the granddaughters of Blikstad III, both living in Norway. They very kindly answered my letters asking for information and advised me to contact their aunt, Vivien Blikstad (the daughter

37 Vida marítima (1929), 10 in: Hemeroteca Digital, Biblioteca Nacional de España.

38 www.baerum.kommune.no. 
of Blikstad III), who lived in Brazil and, who could help me in my research. So I conducted a series of Skype interviews and an e-mail correspondence with Vivien Blikstad in 2012. I am very grateful to her for the information she contributed and for her kind disposition. Much of the information I have received refers to her experience as daughter and granddaughter of Norwegian emigrants in Brazil, and to her stays in Norway as a young student. The phone conversation I had with Sara Blikstad was also important to my work, since I got details about the Blikstads that helped me greatly to understand the space of the family memory.

When asked if she or her parents considered themselves Norwegian or Brazilian, Vivien Blikstad found it difficult to answer; when she was a child, she said, she felt "like a fish without water." Today, she considers herself to be a Western person but a citizen of the world. Her parents arrived to Brazil as adults, even if young, but she and her brothers were born there. The ties with Norway were nevertheless very strong in their childhood and youth. Their parents seem to have had an interest in preserving the Norwegian identity. The family spoke either Norwegian or English in the house, she said, and she learned Portuguese from other people, such as the servants. ${ }^{39}$ When they lived in Santos, they maintained social relationships with Norwegians living there. They attended church once a month, when there were religious services for the Scandinavian community. ${ }^{40}$ According to her, many of the Norwegians in Santos were seamen's wives who stayed in Brazil for two or three years, in order to be closer to their husbands while their babies were small. Sometimes they would stay longer until their children had to enter the school, and then they returned permanently to Norway. ${ }^{41}$ The migration of these women and children was a temporary one. On the contrary, the migration of Vivien Blikstad's parents would be definitive: she and her children live today in Brazil.

Here I think that Vivien contrasts those who live only for some years in Brazil with her family, which had settled in that country even while maintaining networks and strong ties with Norway. Those seamen's wives were temporary immigrants who, because of their husbands' work, lived for some years outside of Norway. The case of Vivien and her family was quite different, and that is why she seems to point out this contrast between their life situations as immigrants.

Language was crucial for the construction of the Norwegian identity. At fourteen, Vivien therefore went to Norway to study, as did also her brothers,

39 Interview with Vivien Blikstad. October, 2012.

40 Ibid.

41 Ibid. 
Eirik and Svein, and her sister, Birgit. Of the four, only Birgit would remain in Norway; she is the mother of Sara and Marta, both residents in this country. During those years, Vivien recalls, they maintained contact with some members of the family who lived in Norway. Those family gatherings created a blend of the cultural influences of the Blikstads. She gives an example: "We used to gather for some special celebrations at my great aunt's, Angelita [born in Gijón, Spain, and the daughter of Blikstad I], who would prepare Spanish-style African chicken." ${ }^{42}$ The cultural blending is highly evident here: the Brazilbased Vivien is speaking in Norwegian, the "African chicken" is a tropical recipe, and the "Spanish style" denotes the Spanish influence on the family.

There is no doubt that the internationality of the Blikstads' migration led them to assume identities involving more than one society, and as such transmigrants they "develop identities within the social networks that connect them simultaneously with two or more societies." ${ }^{33}$ Gathering for Christmas with other Norwegian temporary immigrants to Brazil, like the families of seamen resident in Santos, or visiting the family members residing in Norway when going to study in there, as in the case of Vivien and other Blikstads living in Brazil, reinforces the Norwegian ties and networks. But the Blikstads also incorporate the Spanish dimension into their social space, like when Magnus Blikstad III takes his children on a trip around Spain and shows them the places where he was born and lived as a child, where he worked, and where his parents and grandparents lived.

It is also interesting to notice the choice of names, because I think that choosing names typical of the country they reside in entails a wish to integrate into the country where they are immigrants. Many of the children of the Blikstads bear Spanish names, like Eduardo and Angelita, but also Norwegian names like Magnus. From the Norwegian census of 190o, I was able to find out that, when returning from Gijón, the Blikstads brought a Spanish employee, Trinidad Consejo (surely a babysitter, and perhaps also a cook), who stayed in Norway for the rest of her life. ${ }^{44}$ It is possible that she did not speak Norwegian or English, so it is most likely that Spanish was the language of domestic use at the Blikstads' house in Bærum, like Norwegian would be later for the generation of Blikstads in Brazil, where at the house of Blikstad III the same story would repeat itself with other protagonists and another language: there, the servants speak Portuguese, and the young Blikstads learn from them.

\footnotetext{
42 Interview with Vivien Blikstad. October, 2012.

43 Glick Schiller, Bach and Szanton Blanc, 1992: 1-2.

44 Census 1900, Folketelling 1900 for 0219 Bærum herread. In Digitalarkivet, Norway: Internet: http://digitalarkivet.arkivverket.no/ft/person/pfo1037029001253.
} 
As for Norwegian traditions, Vivien recalls that on Christmas they prepared Norwegian Christmas pastries, julekaker, and sang Norwegian carols, julesanger, and many times, after attending the Christmas service at the church, they invited Norwegians to their house where they danced and caroled around the Christmas tree. ${ }^{45}$ The preparations for the celebration of Christmas started as early as November with the making of Christmas ornaments and the Christmas pastries. It is worth mentioning that these traditions were passed down to Vivien by her mother, born in Brazil, and by her grandparents on her mother's side, who emigrated first to the United States and then to Brazil.

In Vivien's case, the Christmas traditions seem mainly related to the memory of her childhood and her life in Santos. At ten she moved to São Paulo, and her father bought a farm in Junediai, sixty kilometers from São Paulo. Two of her brothers still live there, although the farm was expropriated by the state to turn it into a park. As for the celebration of May 17, the Norwegian National Day, she says that "it was easier to celebrate it in Santos because São Paulo was a huge city, and the Norwegians were more scattered."46

As to the memory of her grandfather and her great-grandfather (that is, Blikstad II and the patriarch Blikstad I), Vivien's memory has less to tell. She finds it difficult to point out the family businesses of her grandfather in Spain, but remembers touring the north of Spain with her father when she was very young. "He wanted to show us where he had lived," she recalled, "We went to Bilbao, Castro Urdiales, Santander, etc."47 About Consul Blikstad, her greatgrandfather, she remembers some specific details but seems to know little about his life in Spain. Finally, at my request, she adds that the only person who could tell something about her grandfather would be his cousin Alf Blikstad, who lives with his wife, Bettina, in Gibraltar. ${ }^{48}$

\section{Conclusions}

The Blikstads' migratory tradition and the establishment of networks of weak ties, especially by the patriarch in this family saga, Magnus T. Hauff Blikstad (Blikstad I), meant an economic boost for the family and made possible the accumulation of economic, social, and cultural capital. Over the years, the

\footnotetext{
45 Ibid.

46 Ibid.

47 Interview with Vivien Blikstad. October, 2012.

48 Interview with Vivien Blikstad. I tried to locate him in November 2012, on occasion of a visit to Malaga, without success.
} 
Blikstads had also created a network of strong family ties, all of which enabled their economic ascent to take place in periods when the economy favored commerce and global business. This was at first an ascent as entrepreneurs of national and international companies, and later as qualified employees of international companies in Brazil. The identity of the Blikstads goes from Norway, through the language and habits, to the Brazilian identity, language, habits, and residence. Their identity is more global than national, and is traversed by the comings and goings through the spaces they have covered as emigrants.

The Blikstads can be considered as an example of transnationality and of what being transmigrants means; they develop identities that connect them with two or more societies, just like Glick describes as typical of transmigrants. ${ }^{49}$ There is a nexus between these elements, and this nexus is the Norwegian language. But they nevertheless took an interest in learning the local languages in the places where they lived, and moreover, they participated in the social and cultural lives of those countries. In this sense, Blikstad I developed an important work of cultural and social support in Asturias in Spain, but he also took part in the political life of Norway as mayor of Bærum. This internationality is also visible in the study stays abroad he secured for his children, something that allowed them to create new links and relationships in other environments. The creation of links in the business and entrepreneurial society in Spain no doubt allowed Blikstad I to carry out a profitable entrepreneurial activity.

Among the Blikstad family in Brazil, the Norwegian language and customs have been woven together with the language, customs, and behaviors acquired in that country. The national Norwegian or Brazilian is overcome and replaced with a new space, not only of shared activities but also of shared identities, and is marked by the comings and goings through the spaces they traversed as emigrants. In Brazil, Blikstad III designed a series of both family and friendship networks with other Norwegians, whether they came from the United States, as was the case with his parents-in-law, or from Norway itself, like the other Norwegian immigrants belonging to the Blikstad family, or simply with other Norwegians residing there either temporarily, like the seamen's families, or permanently.

49 Glick Schiller, et al., (1992), 1-2. 